\title{
Reconnaissance Surficial Geologic Map of the Taylor Mountains Quadrangle, Southwestern Alaska
}

By Frederic H. Wilson

Pamphlet to accompany

Scientific Investigations Map 3334

Version 1.2, December 2017

2015

U.S. Department of the Interior

U.S. Geological Survey 


\section{U.S. Department of the Interior \\ RYAN K. ZINKE, Secretary}

\section{U.S. Geological Survey \\ William H. Werkheiser, Acting Director}

U.S. Geological Survey, Reston, Virginia: 2015

Revised: October 2017 (ver. 1.1)

Revised: December 2017 (ver. 1.2)

For more information on the USGS-the Federal source for science about the Earth, its natural and living resources, natural hazards, and the environment-visit https://www.usgs.gov/ or call 1-888-ASK-USGS (1-888-275-8747).

For an overview of USGS information products, including maps, imagery, and publications, visit https://www.usgs.gov/pubprod/. To order USGS information products, visit https://store.usgs.gov/.

Any use of trade, firm, or product names is for descriptive purposes only and does not imply endorsement by the U.S. Government.

Although this information product, for the most part, is in the public domain, it also may contain copyrighted materials as noted in the text. Permission to reproduce copyrighted items must be secured from the copyright owner

\section{Suggested citation:}

Wilson, F.H., 2017, Reconnaissance surficial geologic map of the Taylor Mountains quadrangle, southwestern Alaska (ver. 1.2, December 2017): U.S. Geological Survey Scientific Investigations Map 3334, 12 p., 1 sheet, https://doi.org/10.3133/sim3334.

ISSN 2329-132X (online) 


\section{Contents}

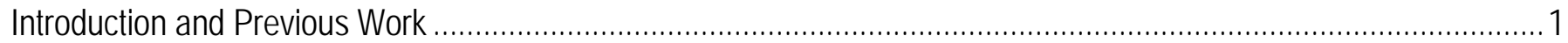

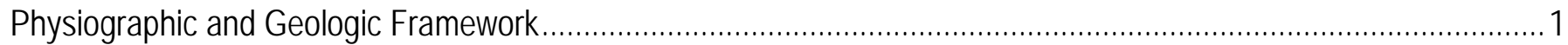

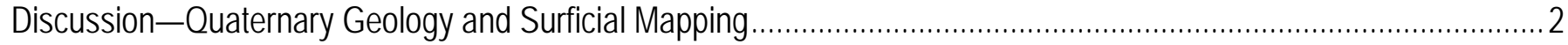

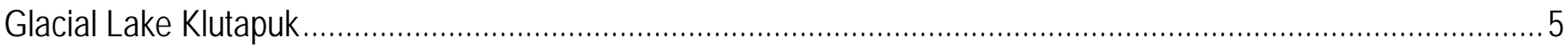

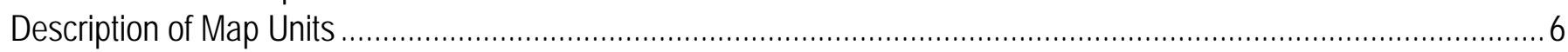

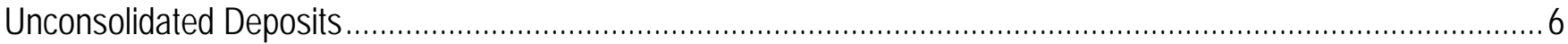

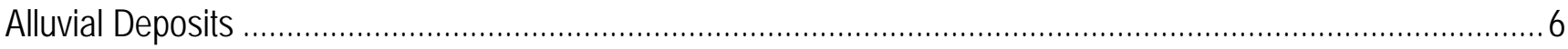

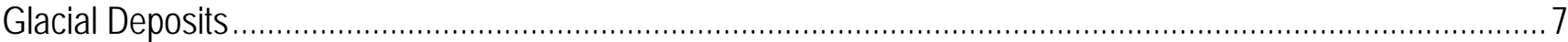

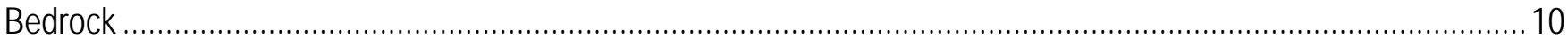

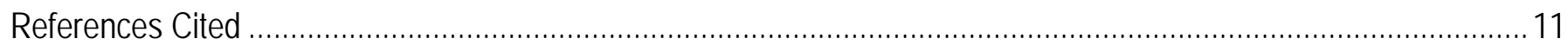

\section{Figures}

1. Physiographic provinces of southwestern Alaska after Wahrhaftig (1965).......................................... map sheet

2. Photograph looking north toward Nishlik Lake map sheet

3. Google Earth image showing the Hoholitna Fault cutting surficial deposits in the northwest Taylor Mountains quadrangle map sheet

4. Vertical air photograph showing glaciolacustrine fan delta deposits in Klutapuk Creek and adjacent valleys map sheet

5. Eroded remnants of outwash fans surround an unnamed lake in the spillway between Moose and McGeary Creeks. map sheet

\section{Tables}

1. Correlation of glacial advances in the Taylor Mountains quadrangle 


\title{
Reconnaissance Surficial Geologic Map of the Taylor Mountains Quadrangle, Southwestern Alaska
}

\author{
By Frederic H. Wilson
}

\section{Introduction and Previous Work}

This map and accompanying digital files are the result of the interpretation of aerial photographs from the 1950s as well as more modern imagery. The area, long considered a part of Alaska that was largely not glaciated (see Karlstrom, 1964; Coulter and others, 1965; or Péwé, 1975), actually has a long history reflecting local and more distant glaciations. An unpublished photogeologic map of the Taylor Mountains quadrangle from the 1950s by J.N. Platt Jr. was useful in the construction of this map. Limited new field mapping in the area was conducted as part of a mapping project in the Dillingham quadrangle to the south (Wilson and others, 2003); however, extensive aerial photograph interpretation represents the bulk of the mapping effort. The accompanying digital files show the sources for each line and geologic unit shown on the map.

I used the Platt and Muller 1950s-era aerial photographic interpretation map as the starting point for the surficial geology; their unpublished data were produced using a reconnaissance quality topographic base map. In addition to transferring their data to a modern base to use as a guide, all of the photographs were re-examined. As result, in a number of areas, the features have been reinterpreted and the linework revised. A major difference between the maps is the recognition of much more extensive glacially dammed lake deposits and reassignment of some glacial deposits to different glacial events.

\section{Physiographic and Geologic Framework}

West of the Alaska and Aleutian Ranges (hereafter the Alaska-Aleutian Range), primarily in the region of Lake Clark, glacial landforms consisting primarily of end or recessional moraines and glaciolacustrine deposits dominate the landscape in the Nushagak-Big River Hills and Nushagak-Bristol Bay Lowland divisions of the Western Alaska physiographic province of Wahrhaftig (fig. 1; 1965). The Taylor Mountains quadrangle encompasses parts of the Western Alaska and Ahklun Mountains physiographic provinces (fig. 1, map sheet) defined by Wahrhaftig (1965). The majority of the quadrangle lies within the Western Alaska province, much of that in the Nushagak-Big River Hills division. The northwest part of the quadrangle lies within the Kuskokwim Mountains division (not shown in figure), separated by a small expanse of the Holitna Lowland division. The southern edge of the quadrangle lies within the Nushagak-Bristol Bay Lowland division. The remainder of the quadrangle, the southwest part, lies with the Ahklun Mountains province.

Southeast of the Mulchatna River valley, which traverses the southeast Taylor Mountains quadrangle, these deposits are largely of late Wisconsin (latest Pleistocene) and Holocene age and commonly associated with the Brooks Lake glaciation (Detterman, 1986). Arcuate end and recessional moraines formed dams that produced a large number of ephemeral lakes; many lakes in the Lake Clark and Iliamna quadrangles, including the largest of all, Iliamna Lake, are remnants of these earlier lakes. 
Lacustrine deposits west of Iliamna Lake, as well as deposits along the many of the rivers of the region, provide evidence these lakes were more extensive in the past.

The bulk of the map area consists of heavily vegetated rolling hills that may be covered by local accumulations of eolian deposits including loess. Originally interpreted as never glaciated (see for example, Péwé, 1975), extensive evidence from photo interpretation suggests the past presence of local alpine glaciers, small ice caps, and large ephemeral glacial lakes, most likely of pre-late Wisconsin age and probably of pre-Wisconsin age. Glacially derived erratic boulders and cobbles found on many ridges in the eastern Taylor Mountains quadrangle suggest an earlier Pleistocene and possibly older areally extensive glaciations. In the southwestern part of the quadrangle, the Ahklun Mountains province, the mountains and beautiful finger lakes show strong effects from Pleistocene and Holocene glaciation (Briner and Kaufman, 2000). In particular, the finger lakes of Wood-Tikchik State Park are welldeveloped landlocked fjords (fig. 2, map sheet). Extensive glacial deposits provide abundant evidence for glaciers that advanced into the quadrangle from the east and west, and probably coalesced in the southern part of the quadrangle during the early Pleistocene.

Structurally, the map area is cut by a number of major known and inferred faults. In the extreme northwest part of the map area, the Hoholitna Fault (fig. 3, map sheet), long considered an extension of the Denali Fault system of central Alaska, has a trace that cuts surficial deposits, that indicates it is presently active. Offset along this fault is traditionally considered to have a right-lateral sense of motion; however, a recent aeromagnetic survey (Saltus and Milicevic, 2004) suggests that the fault system in this area may actually have left-lateral motion. The so-called Mulchatna fault diagonally crosses the southeast part of the quadrangle trending northeast-southwest (Beikman, 1980; Mohadjer and others, 2006); however, other than a topographic lineament, there has been until recently little solid geologic or geophysical evidence to support its existence. The aeromagnetic survey of the Dillingham and Taylor Mountains quadrangle (Saltus and Milicevic, 2004) shows a definitive magnetic discontinuity along a logical extension of the fault trace; however there are no known exposures of the rocks that yield the magnetic signature on either side of the fault. The linear character of the Mulchatna River valley in the adjacent Lake Clark quadrangle is the primary evidence cited for the Mulchatna fault. This asymmetric U-shaped linear valley, if it is of glacial origin, mostly likely predates the Wisconsin glaciation of the region; by and large late Wisconsin glaciers did not reach the Mulchatna River and early(?) Wisconsin glaciers reached it only locally (F.H. Wilson, unpub. data).

Bedrock along the northeast margin of the quadrangle consists of dolostone, limestone, orthoquartzite, and minor chert and is thought to be as old as Proterozoic age (Blodgett and Wilson, 2001; R.B. Blodgett, F.H. Wilson, M.L. Miller, and C.D. Blome, USGS, unpub. data). In the northwest part of the quadrangle, Pliocene-age basalt is present at Flat Top Mountain (Cady and others, 1955; Reifenstuhl and others, 1985). Paleozoic and Mesozoic rock units, including mélange, are found in the southwestern part of the quadrangle (Wilson and others, 2006). However, the majority of the quadrangle is underlain by Cretaceous-age graywacke, siltstone, and shale of the Kuskokwim Group (Cady and others, 1955; Wilson and others, 2006; M.L. Miller and others, USGS, unpub. data); that is in turn intruded by latest Cretaceous to early Tertiary granitic plutons. The Taylor Mountains, in the northcentral part of the quadrangle, and the Shotgun Hills, in the western part of the quadrangle, are distinct mountain masses that are underlain by large plutons. In part due to their relative height above the surrounding country, they supported alpine glacier complexes in the late Wisconsin.

\section{Discussion-Quaternary Geology and Surficial Mapping}

The Quaternary geologic units shown on this map are the products of multiple glacial events, as well as periglacial processes in the unglaciated and less recently glaciated areas. The map area also lies within the zones of discontinuous and sporadic permafrost (Ferrians, 1965; Jorgenson and others, 2008). 
Solifluction deposits have been locally mapped in the eastern and northeastern part of the map area. Additionally, deposits interpreted as silt and peat that may, in part, represent loess are also present in the northeastern part of the map area. Alluvial and colluvial deposits are derived from eroding bedrock and, most commonly, reworking of glacial deposits in the southeast and southwest parts or the map area. Surficial deposits in much of the map area are either direct deposits of glaciers, their outwash, or glaciolacustrine deposits related to the glaciers. Deposits of Holocene, late Wisconsin, and presumed early Wisconsin age are recognized in the map area, and landforms and glaciolacustrine deposits suggest that earlier glacial episodes had significant impact.

Mertie (1938) was the first to report and discuss the glacial deposits in the southwestern part of the Taylor Mountains, although he did not map them. On the Alaska Peninsula, Abrahamson (1949) named the deposits of the Mak Hill glaciation and Muller (1953) named the deposits of the Brooks Lake glaciation; these names are extended into the eastern part of the Taylor Mountains quadrangle here. Muller (1953) briefly discussed the glacial deposits in the western Nushagak River basin. The Aleknagik, Okstukuk, and Iowithla glaciations were named by J.N. Platt Jr. and E.H. Muller on an unpublished USGS map manuscript for the Dillingham quadrangle, and by J.N. Platt Jr. in the Taylor Mountains quadrangle (apparent date about 1957). Platt and Muller correlated the Aleknagik glaciation with the Brooks Lake glaciation, and the Okstukuk glaciation with the Mak Hill glaciation, and interpreted the Iowithla glaciation as a yet older event. Alternately, Lea (1989) correlated the Aleknagik glaciation with the Iliamna advance of the Brooks Lake glaciation, and the Okstukuk glaciation with the Kvichak advance of the Brooks Lake.

Deposits of the youngest glacial advances are located in cirques, and include moraines of very limited extent and, locally, outwash deposits. Rock glacier deposits are also present; and though the rock glaciers may be active, they most likely represent deposits formed during Neoglacial events. Earlier deposits of the late Wisconsin Brooks Lake glaciation (Detterman, 1986) are well represented on the west side of the Alaska-Aleutian Range which forms the topographic backbone of southwestern Alaska; the oldest of these deposits reach the southeast corner of the Taylor Mountains quadrangle. The western periphery of the map area is conceptually the glacial mirror image (?) of the western Alaska-Aleutian Range. During the late Wisconsin, glaciers assigned to the Aleknagik and older Okstukuk advances flowed eastward from the Ahklun Mountains (also locally called the Wood River Mountains) southwest of the map area. These glaciers carved deep, fjord-like glacial lakes and left extensive morainal and outwash deposits. We suggest that these advances correlate approximately in time with the Brooks Lake glaciation of the Alaska-Aleutian Range (table 1), the timing of which is supported by Manley and others (2001), who placed radiocarbon and morphological constraints on the age of advances in the Ahklun Mountains. In their interpretation, the late Wisconsin Aleknagik and Okstukuk glaciations are advanced from the Ahklun Mountains. In part, these glacial deposits rim and form the dams that contain the spectacular finger lakes or land-locked fjords of the Togiak-Tikchik and Wood River region. The Taylor Mountains and Shotgun Hills also supported small, late (?) Wisconsin alpine glaciers.

Table 1. Correlation of glacial advances in the Taylor Mountains quadrangle.

\begin{tabular}{|l|l|l|l|}
\hline Age & $\begin{array}{c}\text { Wood River Mountains (J.N. Platt } \\
\text { and E.H. Muller, USGS, unpub. data) }\end{array}$ & \multicolumn{2}{|c|}{ Alaska Peninsula (Detterman, 1986) } \\
\hline Holocene & Unnamed & Neoglaciation & \\
\hline Late Wisconsin & Aleknagik glaciation & Brooks Lake glaciation & $\begin{array}{c}\text { Iliuk advance } \\
\text { Newhalen advance } \\
\text { Iliamna advance }\end{array}$ \\
& Okstukuk glaciation & Kvichak advance \\
\hline Early Wisconsin & Iowithla glaciation & Mak Hill glaciation \\
\hline Pre-Wisconsin & Unnamed glaciation & Johnston Hill (?) glaciation and "oldest drift" \\
\hline
\end{tabular}


Outboard (or down-glacier) from the Brooks Lake and Okstukuk deposits there are fairly wellpreserved end moraines of the Mak Hill and Iowithla glacial advances, in the eastern and western part of the map area, respectively. Outwash deposits derived from the Mak Hill advance apparently have very limited extent. No drainages clearly derived from melting ice of the Mak Hill glacier are apparent other than a relatively minor abandoned channel from Old Man Creek to the Nushagak River, which was diverted to the present Old Man Creek as it cut across the terminal moraine of the Mak Hill advance. Other meltwaters from the Mak Hill glacier appear to have formed a temporary lake along the eastern boundary of the map area. This lake was drained after the Mulchatna River cut through the terminal moraine of the Mak Hill glacier. The lack of drainage pathways for the Mak Hill glacier and outwash is curious. A definitive explanation is not apparent; however, the Mak Hill glaciers may have stagnated in place and melted very slowly.

Even older glacial deposits in very subdued form are found outboard of these deposits and the landforms of the region show subtle evidence of very old glaciations. In the north central part of the map area, old glaciations are reflected in broad alluviated valleys containing underfit streams, scoured landforms, erratic boulders on ridge tops, and deposits that appear to be outwash fans.

In the east-central and central Taylor Mountains quadrangle, underfit streams that are dominantly south-flowing tend to hug their northern and western valley walls, suggesting general uplift from the southeast. This is also the direction from which the most massive (or extensive) ice accumulated during the late Wisconsin and earlier times, and suggests that a component of uplift in the Taylor Mountains region could be isostatic.

The glacial moraines in the southeastern part of the Taylor Mountains quadrangle tend to have well-preserved glacial landforms that largely control drainage patterns and locally show relatively abundant kettles and kettle lakes. Typically, the oldest of the late Wisconsin moraines, correlated with the Kvichak advance of Detterman (1986), has an extensive outwash fan that may, in part, represent a long still-stand, and also consist of outwash from younger late Wisconsin advances. In the Dillingham quadrangle to the south, the outwash fan outboard of the Kvichak terminal moraine extends at least 20 $\mathrm{km}$ downstream from the terminal moraine (Stilwell and Kaufman, 1996).

West and north of the Mulchatna River valley in the northeastern Taylor Mountains quadrangle, glacial landforms become much more subdued. Isolated mountain masses are separated by broad alluvial valleys. The valley fill is interpreted to be composed of older outwash deposits filling even older glacially modified valleys. In the north central part of the map area, the Taylor Mountains are an isolated mountain mass that supported alpine glaciers of presumed latest Pleistocene age and possible Holocene age. In the northwestern Taylor Mountains quadrangle, very subdued morainal landforms are present along the Hoholitna River. South of the Hoholitna River, the mountains show a variety of presumably glacially derived landforms. Locally, well-developed cirques at the head of the Nushagak River contrast with more subdued and lower topography south of the river headwaters and into the Mulchatna River valley. This more subdued topography has the appearance of being "drowned" in outwash that is derived from local sources as well as from the Alaska-Aleutian Range to the east; in a sense it is drowned, as a lake formerly filled many of the valleys of the upper Nushagak River in the southcentral part of the Taylor Mountains quadrangle. Other smaller lakes were damned in in the vicinity of the Mosquito River in the east part of the map area and in the lowlands around Shotgun Creek north of the Shotgun Hills.

The central Taylor Mountains quadrangle has traditionally been considered part of unglaciated central Alaska (see for example, Péwé, 1975). However, photo interpretation clearly indicates that the Taylor Mountains and Shotgun Hills were glaciated relatively recently, and landforms elsewhere, such as at Finn and Butch Mountains, suggest alpine glaciers were common in the region at an early stage. Broad U-shaped alluvium-filled valleys, underfit streams, and apparent high-level abandoned channels suggest a local ice cap. However, the age of this event is uncontrolled, although it is unlikely to have been during the late Wisconsin. More subtle evidence for earlier glaciations in the Taylor Mountains 
quadrangle appears in areas of scoured bedrock (sb), reworked morainal deposits (ud), and deposits of presumably glacially dammed lakes (gl) in the central and northeast part of the quadrangle.

Within the Taylor Mountains quadrangle, a drainage divide exists in the vicinity of the Shotgun Hills extending eastward to include the Taylor Mountains, northern Nushagak Hills, and the basin of the Holitna River in the northeast part of the quadrangle. Drainage from glaciers in the northern Wood River Mountains, the northern Shotgun Hills, and the Taylor Mountains flowed northward, eventually to the Kuskokwim River. The southern parts of the map area are drained by the Nushagak River, which roughly divides the glacial deposits derived from the Alaska-Aleutian Range from the less extensive deposits derived from the Wood River Mountains. In late Wisconsin time, the river mainly served as the ultimate drainage for most waters from these distant ice fronts. However, in pre-Wisconsin time it appears that the river was dammed by advancing ice from both directions in the adjacent Dillingham quadrangle, producing a temporary lake, Glacial Lake Klutapuk, in the Taylor Mountains quadrangle. Another smaller temporary lake formed in the eastern part of the map area where the Mosquito River was also damned by the pre-Wisconsin ice. In the northern part of the map area, another temporary lake apparently formed in the Holitna River-Shotgun Creek basin. Unpublished mapping by T.K. Bundtzen (Pacific Rim Geologic Consultants, written commun., 2003) in the Sleetmute quadrangle to the immediate north of the map area suggests the Holitna River may have been dammed by a glacier derived from the Alaska Range. If this was the case, then the deposits mapped in this basin labeled fg may instead be glaciolacustrine sediments. No other source for a dam in this basin is apparent.

\section{Glacial Lake Klutapuk}

A particularly spectacular area of apparent lake deposits occurs in the Klutapuk Creek valley in the central part of the quadrangle. A large quantity of coarse outwash was deposited in glaciolacustrine fans (fig. 4, map sheet) that have since been largely eroded. These fans were deposited in a lake dammed by glaciers flowing from the Wood River Mountains to the west and the Alaska-Aleutian Range to the east, joining just to the south of the creek valley. These glaciers dammed the Nushagak River and tributary drainages, developing a many-fingered glacial lake extending northward in the quadrangle (Wilson, 2006) and filling many other tributary valleys. Lea (1989) first suggested the presence of such a lake, dammed by advancing glaciers from the east and west. Although absolute age control is lacking, the evidence suggests that this glacier and associated glaciation was significantly earlier than the Wisconsin. Throughout the Taylor Mountains and northern Dillingham quadrangles, entrenched stream valleys containing present-day underfit streams provide ample evidence for significantly higher flow regimes in the past, that are interpreted here as indications of meltwater drainage from waning glaciers. Additionally, abandoned drainage channels cut through both glacial deposits and bedrock, providing further evidence of ample water flow. These features indicate a much larger glacial impact on the landscape than is generally assumed in this part of Alaska. Ultimately, the lake drained as the glaciers receded; there is some evidence in the Dillingham quadrangle to the south (F.H. Wilson, unpub. data) to suggest that lake drainage may have yielded a cataclysmic flood to the ocean.

East of the Nushagak River, drainage from these glaciers developed extensive outwash fans leading to the upper Nushagak River at Big Bend. Eroded remnants of this outwash are visible in upper McGeary Creek (fig. 5, map sheet). The ancestral Nushagak River may have drained towards the Mulchatna River prior to this early glaciation. Outwash and glacial deposits in McGeary Creek blocked this earlier path of the Nushagak River. Subsequent glaciations led to the Mulchatna being blocked by these deposits, eventually forming a lake. 


\section{DESCRIPTION OF MAP UNITS}

\section{UNCONSOLIDATED DEPOSITS}

us Surficial deposits, undivided (Quaternary) - Poorly to well sorted, poorly to moderately well-stratified deposits; consist of an undivided mixture of alluvial, colluvial, glacial, lacustrine, eolian, and swamp deposits. May contain permafrost locally; map area is in a transition zone between a northern area generally underlain by thick to thin permafrost and a southern area containing isolated masses, typically in fine-grained deposits (Ferrians, 1965). Locally subdivided into:

Artificial fill (Holocene) —Disturbed ground around mine in the Taylor Mountains at head of Taylor Creek

Solifluction deposits (Holocene)—Solifluction mantle, interpreted from aerial photographs. Thought to be poorly sorted sand, silt, and clay derived from local upslope bedrock sources in eastern part of quadrangle. May include mixed-in organic matter

Landslide deposits (Holocene) - Coarse, subangular rock fragments to fine sand and silt having poorly to well-developed lobate morphology. Few deposits of this type are recognized in Taylor Mountains quadrangle

Fine-grained deposits (Quaternary) —Silt, sandy silt, and organic bog deposits (peat). These deposits may include areas of old outwash, lacustrine deposits, loess, and alluvial deposits including old terrace deposits and tend to be swampy locally. In northeast part of quadrangle, along floors of valleys, most likely permafrost-rich

Beach deposits (Quaternary) - Moderately well-stratified and sorted sand and gravel on beaches around lakes and abandoned lakes. May include boulders and cobbles locally. Most lakes do not display these deposits at map scale

\section{ALLUVIAL DEPOSITS}

Alluvial deposits-Divided into:

Flood-plain deposits (Holocene) - Mainly gravel and coarse sand; consisting in part of glacial and glaciofluvial material reworked by postglacial streams. Ranges from coarse, subangular rock fragments to fine sand and silt

Alluvial fan and talus deposits (Holocene) — Gravel, silt, and sand, commonly occur at mouth of small side canyons. Ranges from coarse, angular rock fragments to fine sand and silt. Typically has well-developed cone shapes or multiple cones coalescing into aprons

Terrace deposits (Quaternary) — Terrace gravel and sand originally deposited as older alluvium and outwash along stream and river channels. These deposits are likely of multiple ages across map area

Older terrace deposits (Quaternary) - Higher level terrace gravel and sand along the lower Nushagak River and along one stream draining into the Mulchatna River at the eastern edge of map area

Abandoned channel deposits (Pleistocene) — Gravel, sand, and silt in abandoned or underfit stream channels, inferred in part to be relict glacial meltwater channels. Well developed at limits of former glaciers 


\section{GLACIAL DEPOSITS}

Glacial deposits, undivided (Quaternary) — Undifferentiated glacial drift deposited during the last three or more(?) glacial advances. Consist of sand, gravel, and boulders. Include morainal and outwash deposits as well as undivided colluvium, talus, landslide debris, alluvium, and local silt. May include deposits in small cirques, although larger areas of this deposit occur in northeast part of quadrangle along the Hoholitna River. Deposits along the Hoholitna River are significantly older than deposits in cirques, which are likely of late Wisconsin or Holocene age. Where possible, subdivided into:

Glacial deposits in cirques (Holocene or late Wisconsin?) - Includes morainal and outwash deposits in small cirques

Drift, Neoglacial deposits (Holocene)—Small areas of undivided glacial deposits in isolated cirques, largely between Chikuminuk Lake and Lake Chauekuktuli in southwest corner of quadrangle. Age inferred from fresh appearance of deposits. Locally subdivided into:

Outwash, Neoglacial deposits (Holocene)—Stratified sand and gravel derived from formerly existing Neoglacial glaciers. Commonly associated with Neoglacial drift and grades into alluvial deposits 131

Rock glacier deposits (Holocene) - Poorly sorted rock fragments and debris in lobate forms; typically ice-cored, interpreted from aerial photographs

Glaciolacustrine deposits (Pleistocene)—Well-sorted, well-stratified clay, silt, and fine sand deposited in ephemeral pre-glacial and postglacial lakes. May be covered by several feet of muck and peat and are transitional to swamp deposits (map unit fg). Widely exposed in central part of quadrangle where a lake (ancestral Lake Klutapuk) was dammed by coalescing glaciers. Deposits are most likely early Wisconsin or older in age. In southwest part of quadrangle, younger deposits are associated with deposits of late Wisconsin age and indicate larger extents of existing finger lakes

Glaciolacustrine fan deposits (Pleistocene) - Glacial outwash derived fan deltas deposited in ephemeral glacial lakes. Largest deposits are at southern end of ancestral Lake Klutapuk. Other fans were deposited in a lake that developed north of the Shotgun Hills. Interpreted from aerial photographs, but thought to consist largely of sand and gravel

Late Wisconsin glacial deposits (late Pleistocene)-Undivided glacial deposits of late Wisconsin age. Includes deposits of three named glaciations, the Brooks Lake on the east, and the Aleknagik and Okstukuk on the west. Also includes unnamed deposits at Taylor Mountain. Undivided units located on peninsula between Nishlik and Upnuk Lakes and south of Upnuk Lake, as well as in the Shotgun Hills included here. Locally subdivided (west to east) into:

Outwash-Consist of stratified gravel and sand in outwash aprons of the Okstukuk and Brooks Lake glaciations and deposits not assigned to any particular glaciation. Most extensive are deposits associated with the Okstukuk glaciation in the western and southwestern part of the quadrangle. In the southeast part of the quadrangle, stratified gravel and sand outwash 
ak

akg

ako

okd

okg

bk

ig

plains, kame terrace, and pitted outwash deposits reflect the Brooks Lake glaciation, in particular outwash of the Kvichak advance and may include outwash from advances younger than the Kvichak advance. Stratified gravel and sand in outwash aprons in isolated valleys in central and northern parts of map area have no clear association with any particular moraines except in the Taylor Mountains

Drift, Aleknagik glaciation-Glacial deposits including end, lateral, recessional, and ground moraine and outwash. Lea (1989) correlates with Iliamna advance of the Brooks Lake glaciation, suggesting a late Wisconsin age. Most likely includes deposits equivalent to the younger Newhalen and possibly Iliuk advances of the Brooks Lake glaciation. As mapped, also includes deposits derived from the Shotgun Hills, which have previously not been included in the Aleknagik glaciation. Locally subdivided into:

Ground moraine, Aleknagik glaciation-Widely distributed till deposits behind end or recessional moraines of the Aleknagik glaciation. Likely includes organic and glaciolacustrine material

Outwash, Aleknagik glaciation-Stratified gravel and sand of outwash aprons, finer grained, better sorted, and thinner at a distance from associated moraines of the Aleknagik glaciation than near them (J.N. Platt and E.H. Mueller, USGS, unpub. data, 1957)

Drift, Okstukuk glaciation-Glacial deposits including end, lateral, recessional, and ground moraine and outwash. Lea (1989) correlates with Kvichak advance of the Brooks Lake glaciation, suggesting a late Wisconsin age and therefore making this advance equivalent to the Late Wisconsin Maximum (LGM). Locally subdivided into:

Ground moraine, Okstukuk glaciation-Widely distributed till deposits behind end or recessional moraines of the Okstukuk glaciation. Likely includes eolian, organic, and glaciolacustrine material

Drift, Brooks Lake glaciation, Kvichak advance — Consists of end and lateral moraines of the oldest and most extensive of the four advances of the Brooks Lake glaciation. This advance tends to have well-developed and areally extensive outwash deposits in front of the moraines. Generally accepted to be of late Wisconsin age and represents the LGM. A radiocarbon age from outwash along the Kvichak River, $20 \mathrm{~km}$ downstream of the type Kvichak advance moraine (in the Dillingham quadrangle to the south) was interpreted by Stilwell and Kaufman (1996) to date this advance at $26,155 \pm 285{ }^{14} \mathrm{C}$ years B.P. which is analytically identical to a $26,570 \pm 320{ }^{14} \mathrm{C}$ years B.P. date reported by Mann and Peteet (1994) from the equivalent Naknek moraine on the northern Alaska Peninsula, therefore defining the timing of the LGM in this region. However, the distance of the sample site from the morainal deposits makes this date less than conclusive. It may date outwash from a later advance and is in any case a minimum age.

\section{Early Wisconsin glacial deposits}

Drift, Iowithla glaciation (Pleistocene)_Undivided glacial deposits including end, lateral, recessional, and ground moraine and outwash, composed chiefly of unsorted coarse gravel and coarse gravelly till, with silty clay matrix of the Iowithla glaciation, as described by J.N. Platt and E.H. 
Ground moraine, Iowithla glaciation-Ground moraine of unsorted till, as described above, includes some organic and lacustrine material

Outwash, Iowithla glaciation-Stratified gravel and sand of outwash aprons and plains of the Iowithla glaciation

Drift, Mak Hill glaciation (Pleistocene)—Undivided glacial deposits including end, lateral, recessional, and ground moraine, and local outwash deposits considered equivalent to the deposits of the Mak Hill glaciation of Detterman (1986). Generally considered early Wisconsin in age by Detterman (1986). Primarily exposed in southeastern part of quadrangle. Appears to reflect a major advance and a possible re-advance or stillstand as there are two moraine fronts. Locally subdivided into:
\end{abstract}

Mueller (USGS, unpub. data, 1957). Extensively mantled by several feet of silt, muck, and peat, except on knolls and ridges. Older than late Wisconsin age and possibly equivalent to the Mak Hill glaciation in age, hence early Wisconsin. Northeast of Upnuk Lake, a small area of these glacial deposits has been mapped outboard and at much higher elevation than deposits of the Okstukuk advance, but well inboard of other deposits of the Iowithla advance. These deposits appear to represent a later re-advance of the Iowithla glaciers. Although not recognized anywhere else as associated with the Iowithla deposits, evidence of more than one advance of the Mak Hill glaciation can be interpreted from elsewhere on the Alaska Peninsula (Detterman and others, 1981; Riehle and Detterman, 1993). Locally subdivided into:

Ground moraine, Mak Hill glaciation-Ground moraine of unsorted till, as described above, includes some organic and lacustrine material

Outwash, Mak Hill glaciation-Deposits assigned to this unit have very limited extent, especially considering the large size of the Mak Hill moraine. Stratified gravel and sand of outwash aprons and plains of the Mak Hill glaciation. In the quadrangle, primarily occurs along the Mulchatna River

\title{
Drift, unnamed glaciations (early Pleistocene) —Undivided drift, most
} likely reflecting end, ground, and recessional moraine deposits, as well as other glacial and glaciofluvial materials. Extensively mantled by colluvium, silt, muck, and peat. Moraine topography, where recognizable, is much subdued and modified (J.N. Platt and E.H. Mueller, USGS, unpub. data, 1957). These deposits were derived from both western and eastern parts of map area and are the most extensive glacial advance recognized through landforms in the northern part of the map area. These deposits may be equivalent in age to the Halfmoon Bay and Nichols Hill advance exposed in bluff sections along Nushagak and northern Bristol Bay (Lea, 1989). Locally subdivided into:

Ground moraine, unnamed glaciations_-Ground moraine, most likely includes some organic and lacustrine material

Outwash, unnamed glaciations - Stratified gravel and sand of outwash aprons, also most likely includes some organic and lacustrine material. In eastern part of the quadrangle, may include deposits of younger glaciations 
drumlin form. These drumlin forms are surrounded by younger outwash and are thought to reflect drift of an old, unnamed glaciation

\section{BEDROCK}

sb Scoured bedrock-Areas of glacially scoured bedrock locally covered by a thin(?) mantle of unconsolidated surficial deposits. Age of scouring is most likely Quaternary; age of underlying bedrock is early Tertiary or older

Bedrock, undivided-Bedrock of Tertiary and older age including latest Cretaceous to earliest Tertiary age plutons, Tertiary volcanic rocks, Late Cretaceous sedimentary rocks of the Kuskokwim Group and older sedimentary and igneous rocks. Not labelled on map 


\section{References Cited}

Abrahamson, S.R., 1949, Geography of the Naknek region, Alaska: Worcester, Mass., Clark University, Ph.D. dissertation, 148 p.

Beikman, H.M., 1980, Geology of Alaska: U.S. Geological Survey, 1 sheet, scale 1:2,500,000.

Blodgett, R.B, and Wilson, F.H., 2001, Reconnaissance geology north of the Hoholitna River, Taylor Mountains D-1 1:63,360-scale quadrangle, southwestern Alaska, in Gough, L.P., and Wilson, F.H., eds., Geologic studies in Alaska by the U.S. Geological Survey, 1999: U.S. Geological Survey Professional Paper 1633, p. 73-82.

Briner, J.P., and Kaufman, D.S., 2000, Late Pleistocene glaciation of the southwestern Ahklun Mountains, Alaska: Quaternary Research, v. 53, p. 13-22.

Cady, W.M., Wallace, R.E., Hoare, J.M., and Webber, E.J., 1955, The Central Kuskokwim Region, Alaska: U.S. Geological Survey Professional Paper 268, 132 p., 9 plates including 1 map, scale, about $1: 500,000$.

Coulter, H.W., Péwé, T.L., Hopkins, D.M., Wahrhaftig, Clyde, Karlstrom, T.N.V., and Williams, J.R., 1965, Map showing extent of glaciations in Alaska; Compiled by the Alaska Glacial Map Committee of the U.S. Geological Survey: U.S. Geological Survey Miscellaneous Geologic Investigations Map I-415, scale 1:2,500,000.

Detterman, R.L., 1986, Glaciation of the Alaska Peninsula, in Hamilton, T.D., Reed, K.M., and Thorson, R.M., eds., Glaciation in Alaska, the geologic record: Alaska Geological Society, p. 151-170.

Detterman, R.L., Miller, T.P, Yount, M.E., and Wilson, F.H., 1981, Quaternary geologic map of the Chignik and Sutwik Island quadrangles, Alaska: U.S. Geological Survey Miscellaneous Investigations Series Map I-1292, 1 sheet, scale 1:250,000.

Ferrians, O.J., Jr., 1965, Permafrost map of Alaska: U.S. Geological Survey Miscellaneous Geologic Investigations Map I-445, 1 sheet, scale 1:2,500,000.

Jorgenson, Torre, Yoshikawa, Kenji, Kanevskiy, Mikhail, Shur, Yuri, Romanovsky, Vladimir, Marchenko, Sergei, Grosse, Guido, Brown, Jerry, and Jones, Ben, 2008, Permafrost characteristics of Alaska: Institute of Northern Engineering, University of Alaska Fairbanks, 1 sheet, scale 1:7,200,000.

Karlstrom, T.N.V., compiler, 1964, Surficial geology of Alaska: U.S. Geological Survey Miscellaneous Investigations Series Map I-357, 2 sheets, scale 1:1,584,000.

Lea, P.D., 1989, Quaternary environments and depositional systems of the Nushagak Lowland, southwestern Alaska: Boulder, University of Colorado, Ph.D. dissertation, 355 p., 72 figs., 5 tables.

Manley, W.F., Kaufman, D.S., and Briner, J.P., 2001, Pleistocene glacial history of the southern Ahklun Mountains, southwestern Alaska-Soil-development, morphometric, and radiocarbon constraints: Quaternary Science Reviews, v. 20, p. 353-370.

Mann, D.H., and Peteet, D.M., 1994, Extent and timing of the last glacial maximum in southwestern Alaska: Quaternary Research, v. 42, p. 136-148.

Mertie, J.B., Jr., 1938, The Nushagak District, Alaska: U.S. Geological Survey Bulletin 903, 96 p., 2 plates in pocket.

Mohadjer, Solmaz, Wilson, F.H., and Saltus, R.W., 2006, Geologic and geophysical views of the Mulchatna lineament of southwest Alaska [abs.]: Geological Society of America Abstracts with Programs, v. 38, no. 5, p. 17.

Muller, E.H., 1953, Northern Alaska Peninsula and eastern Kilbuck Mountains, Alaska, in Péwé, T.L., and others, eds., Multiple Glaciations in Alaska: U.S. Geological Survey Circular 289, p. 2-3.

Péwé, T.L., 1975, Quaternary geology of Alaska: U.S. Geological Survey Professional Paper 835, 145 p., 3 plates. 
Reifenstuhl, R.R., Decker, John, and Coonrad, W.L., 1985, Compilation of geologic data from the Taylor Mountains D-8 quadrangle, southwestern Alaska: Alaska Department of Geological and Geophysical Surveys Report of Investigations 85-4, 1 sheet, scale 1:63,360.

Riehle, J.R., and Detterman, R.L., 1993, Quaternary geologic map of the Mount Katmai quadrangle and adjacent parts of the Naknek and Afognak quadrangles, Alaska: U.S. Geological Survey Miscellaneous Investigations Series Map I-2032, 1 sheet, scale 1:250,000.

Saltus, R.W., and Milicevic, B., 2004, Preliminary grid data and maps for an aeromagnetic survey of the Taylor Mountains quadrangle and a portion of the Bethel quadrangle, Alaska: U.S. Geological Survey Open-File Report 2004-1293, 6 p., at http://pubs.usgs.gov/of/2004/1293/.

Stilwell, K.B., and Kaufman, D.S., 1996, Late Wisconsin glacial history of the Northern Alaska Peninsula, Southwestern Alaska, U.S.A.: Arctic and Alpine Research, v. 28, no. 4, p. 475-487.

Wahrhaftig, Clyde, 1965, Physiographic divisions of Alaska: U.S. Geological Survey Professional Paper 482, 52 p., 6 plates.

Wilson, F.H., 2006, Ephemeral glacial lakes in southwestern Alaska [abs.]: Geological Society of America Abstracts with Programs, v. 38, no. 5, p. 30.

Wilson, F.H., Hudson, T.L., Grybeck, Donald, Stoeser, D.B., Preller, C.C., Bickerstaff, Damon, Labay, Keith, and Miller, M.L., 2003, Preliminary geologic map of the northeast Dillingham quadrangle (D-1, D-2, C-1, and C-2), Alaska: U.S. Geological Survey Open-File Report 03-105, 13 p., scale 1:100,000.

Wilson, F.H., Mohadjer, Solmaz, Labay, K.A., and Shew, Nora, 2006, Digital datasets for geologic map by Wilson, F.H., Blodgett, R.B., Blome, C.D., Mohadjer, Solmaz, Preller, C.C., Klimasauskas, E.P., Gamble, B.M., and Coonrad, W.L., Preliminary integrated geologic map Databases for the United States: Digital Data for the Reconnaissance Bedrock Geologic Map for the Northern Alaska Peninsula area, Southwest Alaska: U.S. Geological Survey Open-File Report 2006-1303, at http://pubs.usgs.gov/of/2006/1303/. 